This item was submitted to Loughborough's Research Repository by the author.

Items in Figshare are protected by copyright, with all rights reserved, unless otherwise indicated.

\title{
The first enantiomerically pure thiadiazol-3-one 1-oxide and thiatriaza-indene 3-oxide systems chiral at the sulfur atom
}

PLEASE CITE THE PUBLISHED VERSION

http://dx.doi.org/10.1016/j.tetasy.2010.07.025

PUBLISHER

(C) Elsevier

VERSION

AM (Accepted Manuscript)

LICENCE

CC BY-NC-ND 4.0

\section{REPOSITORY RECORD}

Buckley, Benjamin R., Stephen P. Neary, and Mark R.J. Elsegood. 2019. "The First Enantiomerically Pure Thiadiazol-3-one 1-oxide and Thiatriaza-indene 3-oxide Systems Chiral at the Sulfur Atom”. figshare. https://hdl.handle.net/2134/13968. 
This item was submitted to Loughborough's Institutional Repository (https://dspace.lboro.ac.uk/) by the author and is made available under the following Creative Commons Licence conditions.

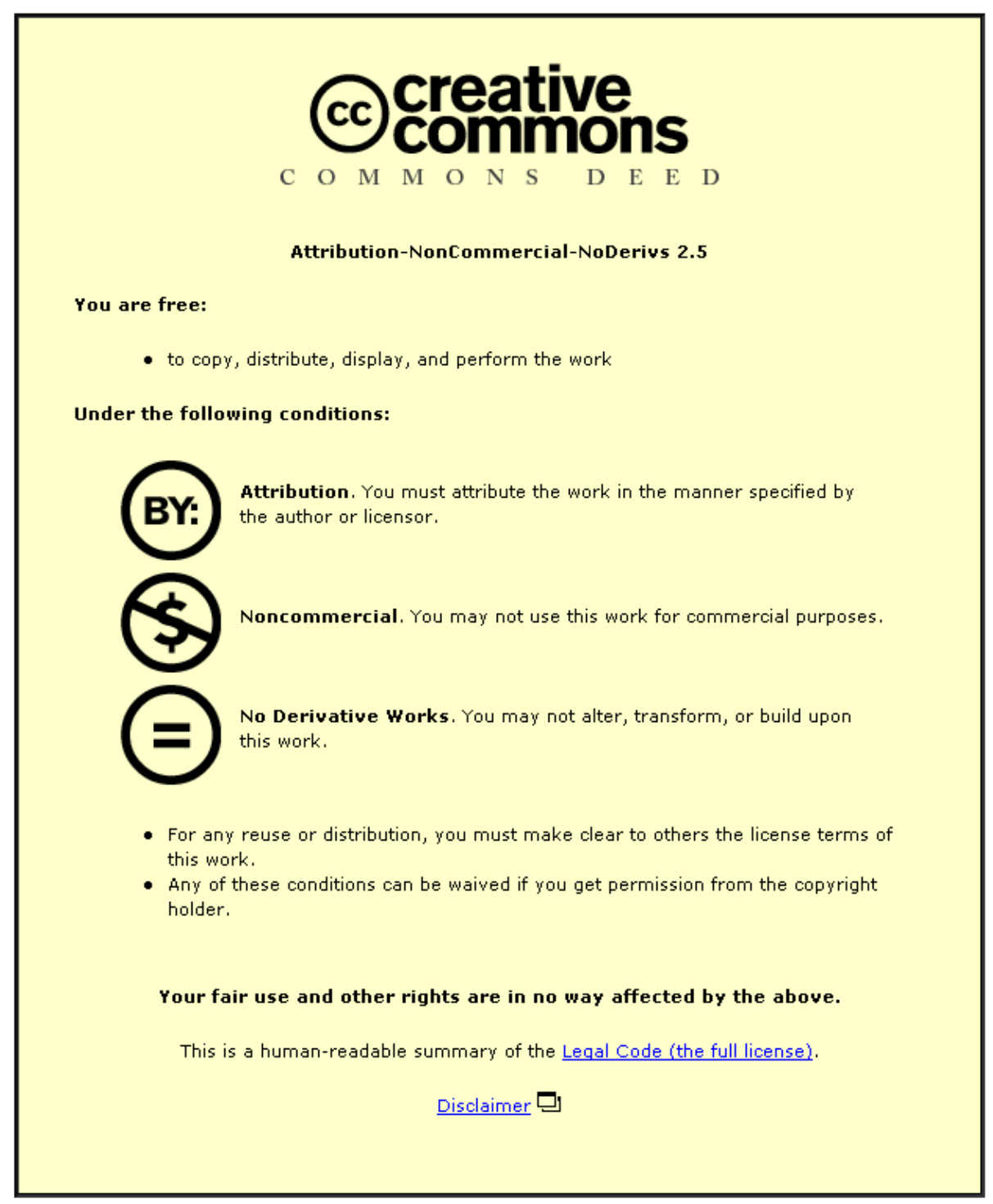

For the full text of this licence, please go to: http://creativecommons.org/licenses/by-nc-nd/2.5/ 


\title{
The First Enantiomerically Pure Thiadiazol-3-one 1-oxide and Thiatriaza-indene 3-Oxide Systems Chiral at the Sulfur atom
}

\author{
Benjamin R. Buckley, ${ }^{*}$ Stephen P. Neary and Mark R. J. Elsegood \\ Department of Chemistry. Loughborough University, Ashby Road, Loughborough, Leicestershire, LE11 3TU, UK
}

\begin{abstract}
The first synthesis of an enantiomerically pure $\mathrm{C}_{2}$ symmetric benzothiadiazole 2-oxide is described along with the first synthesis of a enantiomerically thiadiazol-3-one 1-oxide and a thiatriaza-indene 3-Oxide system both chiral at the Sulfur atom. Excellent levels of diasteroselectivity were observed in the SO installation step, i.e. reaction of the prerequisite bis-amines with thionyl chloride at ambient temperature. (C) 2014 Elsevier Science. All rights reserved
\end{abstract}

\subsection{Introduction}

There are a wide number of reports utilizing a 1,3dinitrogen skeleton as a basis for catalyst/ligand design; for example, $N$-heterocyclic carbenes $\mathbf{1},{ }^{1}$ phosphoramides $\mathbf{2},{ }^{2}$ and thioureas 3 (Figure 1). ${ }^{3}$ Indeed 1,3-amines and imines have themselves been reported as ligands and catalysts. However, there are very few reports regarding the synthesis of structurally related thiadiazolidines 4 or thiadiazolidine oxides $\mathbf{5}$. The majority of reports regarding thiadiazolidine1,1-dioxides 6 relate to their pharmacological properties, ${ }^{4}$ the zwitterion 7 has been used in a Mitsunobu-type reaction ${ }^{5}$ and $\mathbf{8}$ has been employed as a chiral auxiliary in reactions which have traditionally used the Oppolzer sultam. ${ }^{6}$ Thiadiazolidine 1,1-dioxides have also been reported as useful polar aprotic solvents ${ }^{7}$ and as key intermediates for the synthesis of constrained peptides. ${ }^{8} \mathrm{We}$ were particularly attracted to the thiadiazolidine oxides as we postulated that they may be interesting and useful ligands for phosphine free metal-catalysed reactions.

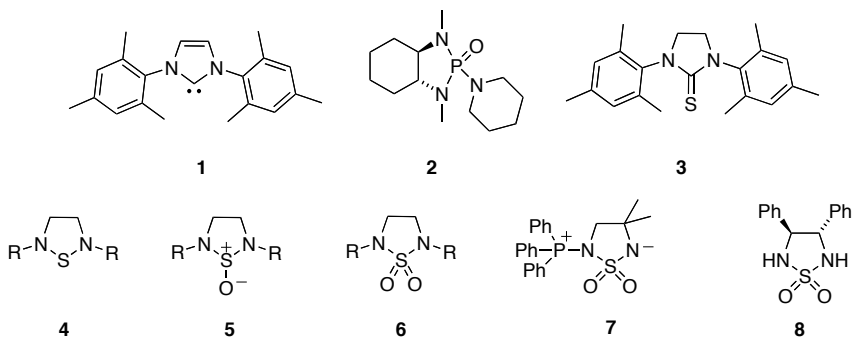

Figure 1. Various 1,3-dintrogen containing compounds

To this end we were the first to report the highly active thiadiazolidine 1-oxide 9 catalyst system in the MizorokiHeck reaction (Scheme 1). ${ }^{9}$ Excellent yields of stilbenes derived from aryl iodides and bromides have been achieved using as little as $0.00002 \mathrm{~mol} \%$ catalyst. The ligand/palladium system can be stored as a stock solution open to air at room temperature with no observable loss of activity for a period of several months.

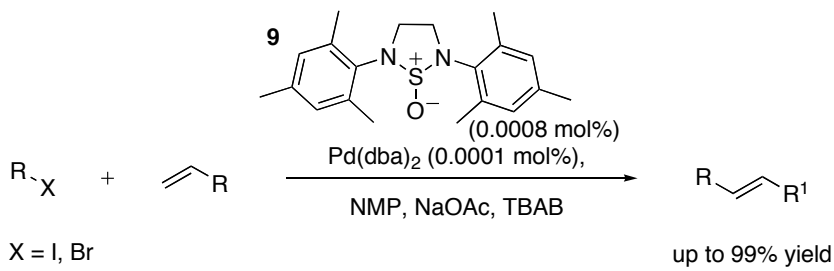

Scheme 1. Application of the thiadiazolidine 1-oxide system for the Mizoroki-Heck reaction.

The synthesis of the mesityl-derived thiadiazolidine 1oxide ligand 9 was easily achieved in two steps; mesityl amine and glyoxal were reacted neat, and upon formation of the bright yellow bis-imine, sodium borohydride/ethanol was added to furnish the bis-amine $\mathbf{1 0}$ in excellent yield (Scheme 2). Treatment of a solution of $\mathbf{1 0}$ in diethylether/triethylamine with thionyl chloride afforded the thiadiazolidine oxide 9 in good yield.

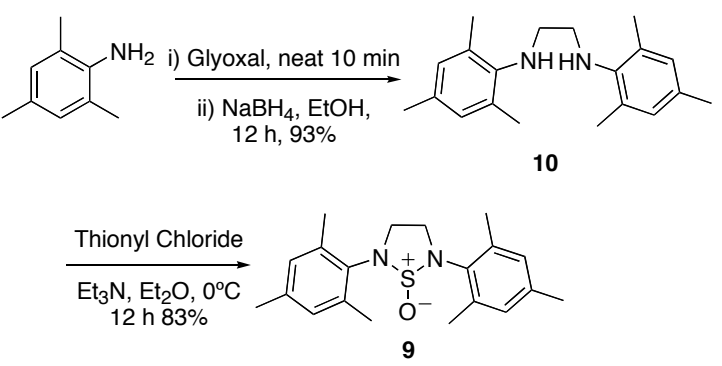

Scheme 2. Synthesis of the thiadiazolidine 1-oxide 9

Our strategy for the development of highly enantioselective catalysis revolves around the fact that if the substituents attached at the nitrogen atoms of a thiadiazolidine 1-oxide system are non-equivalent then the sulfur atom will be chiral. This means that the controlling chiral element for 
asymmetric catalysis will be directly attached to the metal atom and hence will be closer to the site of the reaction. This should then impart high levels of enantiomeric excess. The corresponding phosphine systems have been shown to impart high levels of enantiomeric excess, prominent examples of chiral phosphorus ligand systems are the $\mathrm{C}_{2}$ symmetric non-functionalized bisphospholane ligands DuPHOS, and BPE and the oxyfunctionalized bisphospholanes RoPHOS and BASPHOS, as well as several monophospholanes being part of mono- or bidentate ligands. However, the discovery of new, efficient P-chiral bisphosphanes has been slow, partly because of the difficulties in ligand synthesis, and their synthetic routes are characterized by several disadvantages, e.g. poor air stability, low variability, limited tolerance of functional groups and serious problems during up scaling due to extreme or hazardous reaction conditions. Hence, we believe our systems will add significant value to this highly topical area.

To the best of our knowledge, the synthesis and application of the enantiomerically pure $\mathrm{C}_{2}$ symmetric benzothiadiazoline 1-oxide, and the thiadiazol-3-one 1oxide and thiatriazoline 1-oxide systems chiral at sulfur have not been reported. This communication details our efforts to synthesize the first such examples.

\subsection{Results and Discussion}

For simplicity we initially chose to prepare a $C_{2}$ symmetric ligand. Diver has reported the use of $\mathrm{C}_{2}$ symmetric carbenes based on a benzimidazole structure, ${ }^{10}$ and this prompts us to describe our own results in this area. Such a design of ligand is attractive because both of the enantiomers are, in principle, available, and because the ligands can be readily accessed through a short synthetic sequence; for example, the 1,2-bis- $\alpha$-methylbenzylaniline 11 was easily prepared as shown in Scheme 3. The use of two sequential Buchwald-Hartwig couplings nevertheless proved frustrating as the second reaction consistently gave a lower yield than expected: reaction of the amine with
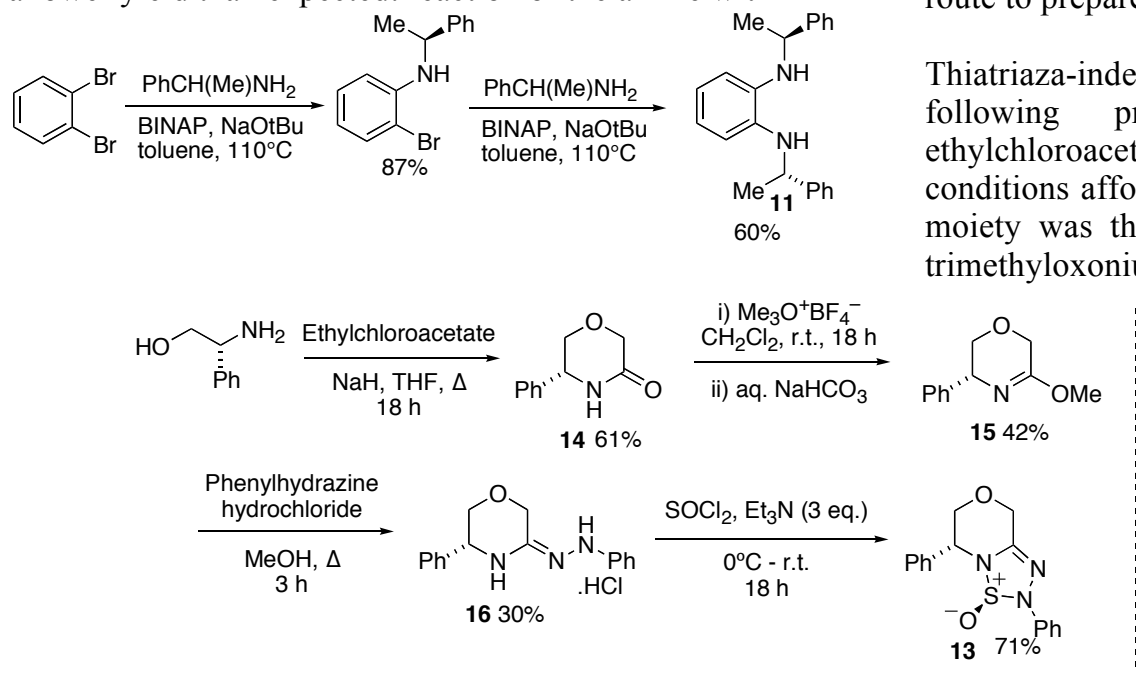

Scheme 6. Synthesis of the thiatriaza-indene 3-oxide $13{ }^{11}$
Scheme 3. Synthesis of the 1,2-bis- $\alpha$-methylbenzylaniline 11. ${ }^{11}$

1,2-dibromobenzene gave the monosubstituted product in an excellent $87 \%$ yield, but attempts to introduce the second amine gave the desired product in no more than a respectable $60 \%$ yield in our hands.

Treatment of 1,2-bis- $\alpha$-methylbenzylaniline 11 with thionyl chloride in diethylether/triethylamine afforded the $\mathrm{C}_{2}$ symmetric benzothiadiazole 2-oxide $\mathbf{1 2}$ in a disappointing $30 \%$ yield (Scheme 4$)$.

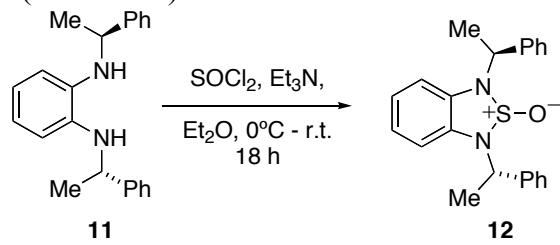

Scheme 4. Synthesis of the benzothiadiazole 2-oxide 12. ${ }^{11}$

We have also attempted the synthesis of a related $\mathrm{C}_{2}$ symmetric system outlined in Scheme 5. ${ }^{12}$ Unfortunately cyclization to incorporate the $\mathrm{SO}$ moiety proved unsuccessful perhaps due to the steric crowding of the two nitrogen atoms.

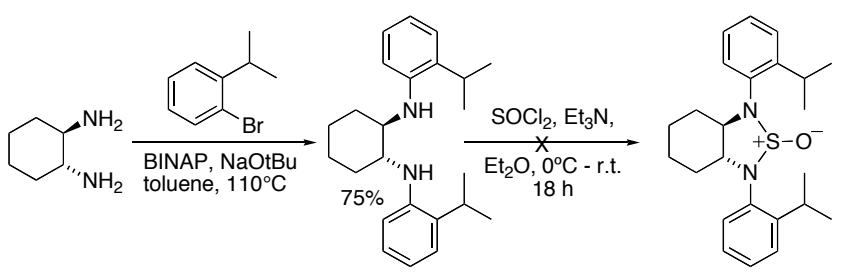

Scheme 5. Attempted synthesis of a cyclohexyldiamine derivative. ${ }^{11}$

In order to develop a synthesis of a system chiral at sulfur we chose to prepare a thiatriazoline 1-oxide as the synthesis of enantiomerically pure unsymmetrical 1,3-diamines has been reported to be non-trivial. ${ }^{13}$ Leeper, ${ }^{14}$ Enders, ${ }^{15}$ Rovis $^{16}$ and others ${ }^{17}$ have shown that the NHC triazolium systems are capable of delivering high enantioselectivities in a variety of transformations, hence we chose a similar route to prepare the thiatriaza-indene 3-oxide 13.

Thiatriaza-indene 3-oxide $\mathbf{1 3}$ was synthesized using the following protocol (Scheme 6): coupling of ethylchloroacetate and phenylglycinol under basic conditions afforded the amide 14 in $61 \%$ yield. The amide moiety was then converted to the imino ether 15 using trimethyloxonium tetraflouroborate Addition of

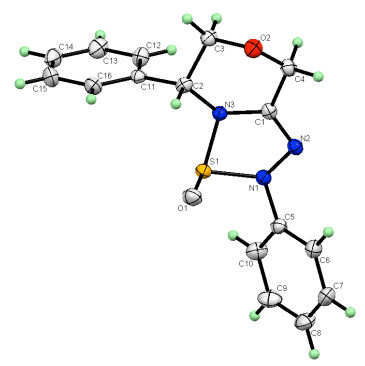

Figure 2. X-ray crystal structure of $\mathbf{1 3 .}$ 
phenylhydrazine hydrochloride afforded the a bis-amine precursor 16 which was suitable for treatment with thionyl chloride under the standard conditions to afford the intended target molecule $\mathbf{1 3}$ as a single diastereoisomer (as determined by ${ }^{1} \mathrm{H}$ and ${ }^{13} \mathrm{C}$ NMR spectroscopy) in $71 \%$ yield. Compound 13 was found to be crystalline and the $\mathrm{X}$ ray crystal structure ${ }^{18}$ is shown in Figure 2. It is interesting to note that the oxygen at sulfur is on the opposite face to that of the phenyl group in the morpholine ring system.

We next turned our attention to preparing a thiadiazol-3one 1-oxide and this was achieved initially by the esterification of phenylalanine $\mathbf{1 7}$, followed by conversion of the ester moiety to the secondary amide 18 using methylamine. The primary amine was then protected with a $p$-methoxybenzyl group and subsequent treatment of the bis-amine 19 with thionyl chloride resulted in the final product $\mathbf{2 0}$ in four simple steps (Scheme 6). Unfortunately compound 20 was an oil and we have as yet been unsuccessful in determining the absolute stereochemistry at sulfur. By ${ }^{1} \mathrm{H}$ and ${ }^{13} \mathrm{C}$ NMR spectroscopy compound 20 appears to be a single diastereoisomer.

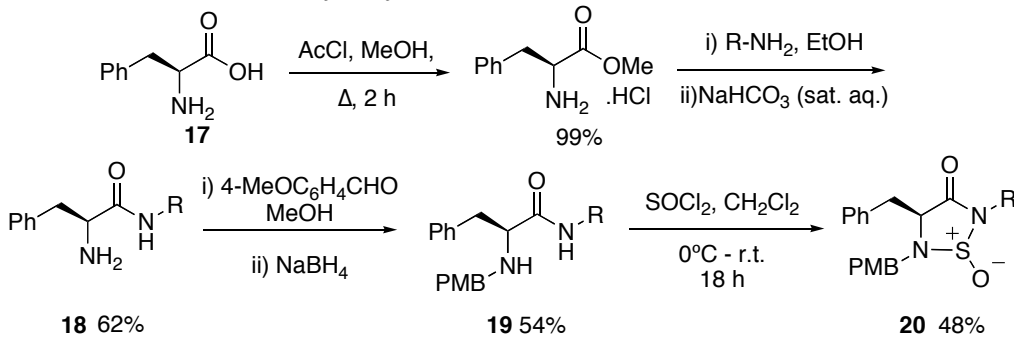

Scheme 7. Synthesis of the thiadiazol-3-one 1-oxide $20 .{ }^{11}$

\subsection{Conclusion}

We have successfully synthesized the first example of a enantiomerically pure $\mathrm{C}_{2}$ symmetric benzothiadiazole 2oxide. We have also prepared the first thiatriaza-indene 3oxide and thiadiazol-3-one 1-oxide systems chiral at the sulfur atom in high diastereoselectivity. We shall now endeavor to apply these and related systems in asymmetric catalysis.

\section{Acknowledgments}

The authors would like to thank Loughborough University for funding a $\mathrm{PhD}$ studentship (SPN) and Research Councils UK for a RCUK fellowship (BRB).

\section{References}

1 (a) Arduengo, A. J. Acc. Chem. Res. 1999, 32, 913; (b) Herrmann, W. A.; Goossen, L. J.: Köcher, C.; Artus, G. R. J. Angew. Chem., Int. Ed. Engl. 1996, 35, 2805; (c) Herrmann, W. A.; Goossen, L. J.; Artus, G. R. J.; Köcher, C. Organometallics 1997, 16, 2472; (d) Seiders, J.; Ward, D. W.; Grubbs, R. H. Org. Lett. 2001, 3, 3225; (e) Perry, M. C.; Burgess, K. Tetrahedron:Asymmetry 2003, 14, 951; (f) Page, P. C. B.; Buckley, B. R.; Christie, S. D. R.; Edgar, M.; Poulton, A. M.; Elsegood, M. R. J.; McKee, V. J. Organomet. Chem. 2005, 690, 6210; (g) Herrmann, W. A. Angew. Chem. Int. Ed. 2002, 41, 1290; (h) Cesar, V.; Bellemin-Laponnaz, S.; Gade, L. H. Chem. Soc. Rev. 2004, 33, 619; (i) Kühl, O. Chem. Soc. Rev. 2007, 36 592; (j) Liddle, S. T.; Edworthy, I. S.; Arnold, P. L. Chem. Soc. Rev. 2007, 36, 1732; (k) Hahn, F. E.; Jahnke, M. C. Angew. Chem. Int. Ed. 2008, 47, 3122; (1) Arnold, O. L.; Casely, I. J. Chem. Rev., 2009, 109, 3599; (m) Lin, J. C. Y.; Huang, R. T. W.; Lee, C. S.; Bhattacharyya, A.; Hwang, W. S.; Lin, I. J. B. Chem. Rev., 2009, 109, 3561; (n) Vougioukalakis, G. C; Grubbs R. H. Chem. Rev., 2010, 110, 1746 .
2 Denmark, S. E.; Heemstra, J. R. J. Org. Chem. 2007, 72, 5668 and references cited therein.

3 Yang, D.; Chen, Y.-C.; Zhu, N.-Y. Org. Lett. 2004, 6, 1577.

4 (a) Hultén, J.; Bonham, N. M.; Nillroth, U.; Hansson, T.; Zuccarello, G.; Bouzide, A.; Åqvist, J.; Classon, B.; Danielson, U. H.; Karlén, A.; Kvarnström, I.; Samuelsson, B.; Hallberg, A. J. Med. Chem. 1997, 40, 885; (b) Bäckbro, K.; Löwgren, S.; Österlund, K.; Atepo, J.; Unge, T.; Hultén, J.; Bonham, N. M.; Schaal, W.; Karlén, A.; Hallberg, A. J. Med. Chem. 1997, 40, 898.

5 Castro, J. L.; Matassa, V. G.; Ball, R. G. J. Org. Chem. 1994, $59,2289$.

6 (a) Ahn, K.-H.; Yoo, D.-J.; Kim, J.-S. Tetrahedron Lett. 1992, 33, 6661; (b) Pansare, S. V.; Rai, A. N.; Kate, S. N. Synlett 1998, 623; (c) Sartor, D.; Saffrich, J.; Helmchen, G.; Richards, C. J.; Lambert, H. Tetrahedron: Asymmetry 1991, 2, 639; (d) Oppolzer, W.; Starkemann, C.; Rodriguez, I.; Bernadinelli, G. Tetrahedron Lett. 1991, 32, 61; (e) Oppolzer, W.; Kingma, A. J.; Pillai, S. K. Tetrahedron Lett. 1991, 32, 4893.

7 Richey, Jr., H.G.; Farkas Jr., J. J. Org. Chem. 1987, 52, 479.

8 (a) Dewynter, G.; Ubaldi, S.; Voyer, N.; Toupet, L. Tetrahedron Lett. 1998, 39, 7434; (b) Boudjabi, S.; Dewynter, G.; Voyer, N.; Toupet, L. Eur. J. Org. Chem. 1999, 9, 2275; (c) Regainia, Z.; Abdaoui, M.; Aouf, N. E.; Dewynter, G.; Montero, J. L. Tetrahedron 2000, 56, 381.

9 Buckley, B. R.; Neary, S. P. Adv. Synth. Catal. 2009, 351, 71.

10 Rivas, F. M.; Riaz, U.; Giessert, A.; Smulik J. A.; Diver, S. T. Org. Lett. 2001, 3, 2673.

11 All novel compounds were characterized by melting point, optical rotation, infra red, combustion analysis, ${ }^{1} \mathrm{H} \&{ }^{13} \mathrm{C}$ NMR spectroscopy, mass spectrometry, and accurate mass analysis.

12 For the synthesis and use of related C2 symmetric carbene ligands/catalysts see for example: (a) Duguet, N.; Campbell, C. D.; Slawin A. M. Z.; Smith, A. D. Org. Biomol. Chem., 2008, 6, 1108; (b) Seiders, T. J.; Ward, D. W.; Grubbs, R. H. Org. Lett., 2001, 3, 3225; (c) Chaulagain, M. R.; Sormunen, G. J.; Montgomery, J. J. Am. Chem. Soc., 2007, 129, 9568. 
13 Struble, J. R.; Kaeobamrung, J.; Bode, J. W. Org. Lett. 2008, 10, 957.

14 Knight, R. L.; Leeper, F. J. J. Chem. Soc., Perkin 1 1998, 1891.

15 (a) Enders, D.; Breuer, K.; Runsink, J.; Teles, J. H. Helv Chim. Acta. 1996, 79, 1899. (b) Enders, D.; Kallfass, U. Angew. Chem., Int. Ed. 2002, 41, 1743.

16 (a) Kerr, M. S.; Read de Alaniz, J.; Rovis, T. J. Am. Chem. Soc. 2002, 124, 10298. (b) Kerr, M. S.; Read de Alaniz, J.; Rovis, T. J. Org. Chem. 2005, 70, 5725.

17 See for related $\mathrm{C}_{2}$ symmetric $N$-heterocyclic carbene examples: (a) Cardinal-David, B.; Raup, D. E. A. Scheidt, K. A. J. Am. Chem. Soc., 2010, 132, 5345 and references cited therein; (b) Li, G.-Q.; Dai, L.-X. You, S.-L. Org. Lett., 2009, 11, 1623; (c) Zhang, Y.-R.; He, L.; Wu, X.; Shao, P. L.; Ye, S. Org. Lett., 2008, 10, 277; (d) Concellón, C.; Duguet, N; Smith, A. D. Adv. Synth. Catal., 2009, 351, 3001 and references cited therein.

18 Crystal data for enantiopure 13: $\mathrm{C}_{16} \mathrm{H}_{15} \mathrm{~N}_{3} \mathrm{O}_{2} \mathrm{~S}, M=313.37$, monoclinic, $P 2_{1}, a=7.3744(4), b=8.8835(5), c=12.0593(7)$ $\AA, \beta=105.7428(8)^{\circ}, V=760.38(7) \AA^{3}, Z=2, D_{\mathrm{c}}=1.369 \mathrm{~g}$ $\mathrm{cm}^{-3}, \mu\left(\mathrm{Mo}_{\mathrm{K}}\right)=0.223 \mathrm{~mm}^{-1}, T=150(2) \mathrm{K}$, colourless plate, $1.05 \times 0.61 \times 0.06 \mathrm{~mm}^{3} ; 8881$ reflections measured as above; 4509 independent, data corrected as above (min. and max. transmission factors: $0.800,0.987), R_{\text {int }}=0.0168$, structure solved by direct methods, $F^{2}$ refinement, $R_{1}=0.0323$ for 4266 data with $F^{2}>2 \sigma\left(F^{2}\right), w R_{2}=0.0826$ for all data; 199 parameters; absolute structure parameter $x=-0.01(5)$. CCDC 783758 contain the supplementary crystallographic data for this paper. These data can be obtained free of charge from The Cambridge Crystallographic Data Centre via www.ccdc.cam.ac.uk/data_request/cif. 